\title{
KUALITAS PENGAJUAN MASALAH MATEMATIKA SISWA DITINJAU DARI BER-IQ SUPERIOR
}

\author{
Ain Putri Rustini ${ }^{1}$, Tatag Yuli Eko Siswono ${ }^{2}$ \\ ${ }^{1,2}$ Universitas Negeri Surabaya, Jln. Ketintang, Surabaya, Jawa Timur \\ ain.17030174072@mhs.unesa.ac.id
}

\begin{abstract}
Problem posing is one way to provide a stimulus for student creative thinking and find out student understanding. This study reports a qualitative study that intended to describe the quality of the mathematical problem posed by students with superior IQ. This study involved two junior high schools accelerated students; The two students were taken from two different schools, namely Junior high school 3 Sidoarjo and Amanatul Ummah. Retrieval of data in this study using assignments that must be completed by students (TPMM) and interview guides based on the results of the subject's written answers. Students do problem posing with superior IQ because IQ above average is one of the supporting factors for creativity. On this research, it can determine the quality of problem posing students with superior IQ. The researcher conducted a triangulation of methods to test the data's credibility; that is, researchers conducted interviews to check the TPMM data's truth. Then the researchers surveyed to increase the number and accuracy of student responses. The valid data were analyzed to obtain conclusions in students' quality of mathematical problems posed by students with superior IQ. The results shown that the quality of mathematical problem posing to accelerated students was in the very high category.
\end{abstract}

Keywords: Problem Posing, IQ (Intelligence Quotient)

\begin{abstract}
Abstrak
Pengajuan masalah merupakan salah satu cara untuk memberikan stimulus berpikir kreatif siswa dan mengetahui pemahaman siswa. Penelitian ini melaporkan studi kualitatif yang dimaksudkan untuk mendeskripsikan kualitas pengajuan masalah matematika siswa ber-IQ superior. Studi ini melibatkan dua siswa kelas akselerasi SMP; dua siswa itu diambil dari dua sekolah yang berbeda yaitu SMPN 3 Sidoarjo dan Amanatul Ummah. Pengambilan data dalam penelitian ini mengunakan tugas yang harus diselesaikan oleh siswa (TPMM) dan panduan wawancara berdasarkan hasil jawaban tertulis subjek. Pengajuan masalah dilakukan siswa yang ber-IQ superior karena IQ diatas rata-rata merupakan salah satu faktor penunjang kreativitas. Dengan adanya penelitian ini dapat mengetahui kualitas pengajuan masalah siswa ber-IQ superior. Untuk menguji kredibilitas data, peneliti melakukan triangulasi metode; yaitu peneliti melakukan wawancara untuk mengecek kebenaran dari data TPMM. Lalu peneliti melakukan survei untuk meningkatkan jumlah dan akurasi tanngapan siswa. Kemudian data yang valid dianalisis untuk memperoleh kesimpulan yang berupa kualitas pengajuan masalah matematika siswa ber-IQ superior. Berdasarkan hasil penelitian menunjukkan bahwa kualitas pengajuan masalah matematika pada siswa akselerasi tergolong dalam kategori sangat tinggi.
\end{abstract}

Kata kunci: Pengajuan Masalah, IQ (Intelligence Quotient)

\section{PENDAHULUAN}

Dalam dunia pendidikan, (Depdiknas, 2007) mengemukakan bahwa matematika merupakan mata pelajaran yang perlu diberikan kepada semua siswa dengan tujuan untuk membekali kemampuan berpikir logis, analitis, sistematis, kritis, dan kreatif, serta kemampuan bekerjasama. Salah satu metode untuk menilai kemampuan matematika tingkat tinggi adalah melalui tugas pengajuan masalah (Mahmudi, 2011). Pengajuan masalah matematika merupakan sebuah tugas yang meminta siswa untuk membuat atau mengajukan soal atau masalah matematika berdasar informasi yang diberikan, dan menyelesaikan soal atau masalah yang telah dibuat tersebut (Siswono, 2008). Menurut (Setyaningsih et al., 2014) Tugas pengajuan masalah bermanfaat untuk membantu siswa dalam 
mengembangkan keyakinan dan kesukaan terhadap matematika, sebab ide-ide matematika mereka dicobakan untuk memahami masalah yang sedang dikerjakan dan dapat meningkatkan kinerjanya dalam menghadapi dan menyelesaikan permasalahan matematika. Dalam kehidupan sehari-hari baik disengaja atau tidak, kita pasti selalu berkaitan dari kegitan berpikir, karena pada kenyataannya berpikir adalah suatu kegitan yang tidak dapat kita hindari. Berpikir adalah suatu kegiatan yang menggunakan akal budi untuk memutuskan atau mempertimbangkan segala kemungkinan yang akan terjadi. Suatu kegiatan mental yang dialami seseorang bila dihadapkan pada suatu masalah atau situasi yang harus dipecahkan merupakan kegiatan berpikir menurut (Siswono, 2008). Pendapat tersebut menunjukkan bahwa ketika seseorang berhadapan dengan suatu permasalahan kemudian berusaha untuk menyelesaikan masalah tersebut, maka seseorang itu telah melakukan suatu kegiatan mental berupa berpikir. Kurikulum Pendidikan di Indonesia sekarang adalah kurikulum 2013, dimana siswa di harapka menjadi manusia yang kreatif (Peraturan Menteri Pendidikan Dan Kebudayaan Republik Indonesia No.58 Tahun 2014 Tentang Kurikulum 2013 Sekolah Menengah Pertama/Madrasah Tsanawiyahz, 2014). Untuk mengetahui kemampuan berpikir kreatif siswa dapat menggunakan pendekatan pengajuan masalah. Dengan perencanaan pengajaran yang baik dapat mengembangkan berpikir kreatif siswa (Gomez, 2013)

Pengajuan masalah intinya merupakan tugas yang diberikan kepada siswa untuk membuat atau merumuskan masalah berdasarkan pemikirannya sendiri yang kemudian dipecahkannya sendiri atau dipecahkan teman lainnya. Salah satu tema-tema terpenting dalam penelitian kreativitas yaitu formulasi masalah (problem formulation) dan pemecahan masalah (Evans, 1991). Dunlap dalam (Siswono, 2005) menjelaskan bahwa pengajuan masalah sedikit berbeda dengan pemecahan masalah, tetapi masih merupakan suatu alat valid untuk mengajarkan berpikir matematis. Di dukung dengan hasil penelitian Hirashima, dkk dalam (Woolf, Aimeur, Nkambou, Lajoie, \& Eds, 2008) bahwa pembelajaran dengan menggunakan pendekatan pengajuan masalah menimbulkan dampak positif terhadap kemampuan pemecahan masalah. Menemukan (discovering) dan memformulasikan masalah sendiri adalah langkah pertama dalam aktivitas kreatif. Pendapat tersebut menunjukan bahwa kemampuan berpikir kreatif dapat dikenali dengan memberikan tugas membuat suatu masalah atau tugas pengajuan masalah. Pendidikan yang bagus dan tepat merupakan salah satu aspek dan sarana utuk mengembangkan kreativitas siswa. Teori Threshold juga mengemukakan bahwa jika seseorang memiliki IQ diatas 120 maka seseorang itu akan sangat sukses dalam kegiatan kreatif (Hayes, 1989). Berdasarkan teori Threshold, (Benedek et al., 2014) berpendapat bahwa IQ diatas rata-rata merupakan syarat perlu berpikir kreatif, bukan syarat cukup. Sehubungan dengan pendidikan, dalam dunia pendidikan dan pengajaran, masalah intelegensi (kecerdasan) merupakan salah satu masalah pokok sehingga masalah kecerdasan banyak dikupas oleh orang (Suryabrata, 2006) Berkaitan dengan kecerdasan, tingkat kecerdasan seseorang dapat diukur dan ditetapkan kategorinya menurut ilmu psikologi. (Uno, 2005) mengungkapkan bahwa tingkat kecerdasan seseorang dapat diukur 
menggunakan tes, dan hasilnya biasa disebut dengan IQ (Intelligence Quotient). (Panda, 2007) juga menyatakan bahwa berdasarkan penelitian yang dilakukan oleh Terman dan Merill ada sepuluh kategori kecerdasan seseorang berdasarkan IQ. Kategori tingkat kecerdasan tersebut beragam, mulai dari tingkat kecerdasan terendah yang disebut dengan idiot sampai pada tingkat kecerdasan tertinggi yang disebut dengan genius. Kemudian (Suharnan, 2005) \& (Rahmawatin, 2013) gommengatakan sehubungan dengan IQ tersebut, berdasarkan penelitian yang dihimpun oleh para ahli, IQ mempunyai peranan penting di dalam beberapa aspek kehidupan manusia, misalnya pencapaian karir, kinerja jabatan, prestasi akademik, kreativitas dan kualitas kesehatan. Intelegensi juga sering diartikan sebagai kecerdasan, kepandaian, atau kepintaran. Solso dalam (Suharnan, 2005) mengemukakan bahwa intelegensi merupakan kemampuan dalam memperoleh dan menggali pengetahuan diri sendiri dengan menggunakan pengetahuan untuk memahami konsep-konsep konkret dan abstrak yang ditemukan, dan menghubungkan objek-objek dan gagasan-gagasan menggunakan pengetahuan dengan cara-cara yang lebih berguna dan bermakna (in a meaningful way) atau efektif.

Selama ini pembelajaran di kelas tentang matematika lebih terfokus pada penyelesaian soal, tetapi untuk pengajuan soal juga perlu diterapkan karena ada beberapa aspek-aspek tertentu yang dapat dicapai dan dikuasai; salah satunya seperti yang diungkapkan oleh English dalam (Siswono, 2004) yang berpendapat bahwa membantu siswa dalam mengembangkan keyakinan dan kesukaan terhadap matematika bisa menggunakan pendekatan pengajuan masalah, karena ide-ide matematika siswa dapat di uji cobakan untuk memahami masalah yang sedang dikerjakan atau diselesaikan dan dapat meningkatkan pemahaman dan kemampuannya dalam pemecahan masalah. Untuk merangsang peningkatan kemampuan matematika siswa, pengajuan masalah juga berperan, karena dalam mengajukan soal siswa perlu membaca dan memahami suatu informasi yang diberikan dan mengkomunikasikan pertanyaan secara verbal maupun tertulis. Berdasarkan pendapat-pendapat di atas, maka pentingnya pengajuan masalah untuk diterapkan dalam pembelajaran matematika di kelas, oleh karena itu pengajuan masalah perlu diberikan dalam pembelajaran matematika di sekolah.

Berkaitan dengan pelajaran matematika yang ada di sekolah, maka kreativitas bisa dihubungkan dengan pengajuan soal. Sehingga kreativitas dalam penelitian ini diartikan sebagai produk kemampuan berpikir kreatif siswa dalam pengajuan soal yang dapat ditinjau dari tiga kriteria kreativitas yang diungkapkan oleh Silver dalam (Siswono, 2008) mengklasifikasikan pengajuan soal berdasarkan aktivitas kognitif matematika dapat dibagi menjadi tiga, yaitu:

a. Pengajuan pre-solusi (presolution posing), yaitu seorang siswa membuat soal berasal dari situasi atau informasi yang diberikan.

b. Pengajuan di dalam solusi (within-solution posing), yaitu seorang siswa merumuskan ulang soal seperti yang telah diselesaikan. Artinya, siswa dapat membuat soal yang dapat mengantarkan pada jawaban soal yang dibuat sebelumnya.

c. Pengajuan setelah solusi (post-solution posing), yaitu seorang siswa memodifikasi tujuan atau kondisi soal yang sudah diselesaikan untuk membuat soal yang baru. Artinya, siswa membuat 
soal baru yang serupa dengan soal yang telah diselesaikan.

Salah satu cara untuk mengetahui kemampuan siswa dapat menggunakan pendekatan pengajuan masalah. Pengajuan masalah dalam penelitian ini adalah pengajuan pre-solusi karena siswa diminta untuk membuat soal matematika berdasarkan informasi yang telah diberikan. Dari penjelasan diatas kreativitas dipengaruhi oleh IQ, dimana kreativitas itu juga sangat dibutuhkan untuk pengajuan masalah matematika. Dengan adanya penelitian ini dapat mengetahui kualitas pengajuan masalah siswa ber-IQ superior, oleh karena itu penelitian ini tentang Kualitas Pengajuan Masalah Matematika Siswa Ber-IQ Superior.

\section{METODE}

Penelitian ini adalah penelitian deskriptif kualitatif yang mendeskripsikan tentang kualitas pengajuan masalah matematika ditinjau ber-IQ (Intelligence Quotient) Superior pada materi Sistem Persamaan Linear Dua Variabel. Subyek dalam penelitian ini adalah siswa yang telah mempelajari materi Sistem Persamaan Linear Dua Variabel dengan ketentuan siswa tersebut memiliki IQ 120 keatas (Superior). Maka dalam penelitian ini, peneliti memilih 2 subyek yang berasal dari siswa akselerasi. Pengambilan subyek Superior berdasarkan klasifikasi IQ menurut (Panda, 2007). Subyek akan diberikan Tes Pengajuan Masalah Matematika (TPMM) yang terdiri dari 1 soal yang berisi informasi-informasi tentang Sistem Persamaan Linear Dua Variabel. Hasil tes pengajuan masalah matematika (TPMM) ini akan di klasifikasikan berdasarkan (Silver \& Cai, 1996) mengklasifikasikan jawaban menurut jenisnya menjadi tiga kelompok. Kemudian dari hasil tes pengajuan masalah matematika (TPMM) akan dilakukan wawancara ke subyek untuk mendapatkan hasil yang valid, kemudian peneliti melakukan survei untuk meningkatkan jumlah dan akurasi tanggapan siswa.

\section{Tabel 1.}

Indikator Kriteria Kategori Kualitas Pengajuan Masalah Matematika Siswa (Rahman, 2004)

\begin{tabular}{|c|l|}
\hline Kategori & \multicolumn{1}{|c|}{ Kriteria } \\
\hline Sangat Rendah & 1. $\begin{array}{c}\text { Masalah yang diajukan tidak sesuai dengan informasi yang } \\
\text { diberikan. }\end{array}$ \\
& $\begin{array}{l}\text { 2. Masalah yang diajukan tidak mengandung hubungan semantic. } \\
\text { 3. Dari segi sintaksis, masalah yang diajukan hanya mengandung } \\
\text { unsur penugasan. }\end{array}$ \\
& 4. Kalimat tidak jelas atau membingungkan. Jika disajikan dalam \\
bentuk diagram, sulit untuk diinterpretasikan.
\end{tabular}




\begin{tabular}{|c|c|}
\hline & $\begin{array}{l}\text { 2. Masalah yang diajukan mengandung } 1 \text { atau } 2 \text { hubungan semantik } \\
\text { 3. Dari segi sintaksis, masalah yang diajukan mengandung unsur } \\
\text { penugasan atau hubungan } \\
\text { 4. Kalimat dapat dipahami dan terarah pada suatu masalah yang } \\
\text { dapat diselesaikan. Jika disajikan dalam bentuk diagram, dapat } \\
\text { diinterpretasikan }\end{array}$ \\
\hline Tinggi & $\begin{array}{l}\text { 1. Masalah yang diajukan sesuai dengan informasi yang diberikan } \\
\text { 2. Masalah yang diajukan mengandung } 3 \text { atau } 4 \text { hubungan semantik } \\
\text { 3. Dari segi sintaksis, masalah yang diajukan mengandung unsur } \\
\text { hubungan atau pengandaian } \\
\text { 4. Kalimat dapat dipahami dengan baik dan terarah pada suatu } \\
\text { masalah yang dapat diselesaikan. Jika disajikan dalam bentuk } \\
\text { diagram, dapat diinterpretasikan dengan baik }\end{array}$ \\
\hline Sangat Tinggi & $\begin{array}{l}\text { 1. Masalah yang diajukan sesuai dengan informasi yang diberikan } \\
\text { 2. Masalah yang diajukan mengandung } 5 \text { hubungan semantik } \\
\text { 3. Dari segi sintaksis, masalah yang diajukan mengandung unsur } \\
\text { pengandaian } \\
\text { 4. Kalimat dapat dipahami dengan baik dan terarah pada suatu } \\
\text { masalah yang dapat diselesaikan. Jika disajikan dalam bentuk } \\
\text { diagram, dapat diinterpretasikan dengan baik dan cepat }\end{array}$ \\
\hline
\end{tabular}

\section{Instrumen Penelitian}

\section{Tes Pengajuan Masalah Matematika (TPMM)}

Informasi : Diberikan uang 65.000 untuk membeli peralatan sekolah sesuai dengan keinginan siswa jumlah masing-masing per barang dengan ketentuan barang yang di sediakan harus terbeli 2 jenis barang saja. Dengan daftar harga berikut; bulpoint seharga 3.000 , buku tulis seharga 4.500, pensil seharga 2.000 , spidol seharga 6.000, penggaris seharga 2.500 dan penghapus seharga 1.000. Uang 65.000 itu harus tersisa minimal 15.000 dan maximal 25.000. Dari barang-barang yang sudah kalian beli silahkan membuat persamaannya dan buatlah soal dari persamaan tersebut !

\section{Pedoman Wawancara}

Wawancara dilakukan setelah subjek mengerjakan TPMM dengan menggunakan fitur Voice Notes WhatsApp.
a. Apa yang anda pahami dengan informasi yang diberikan?
b. Bagaimana cara anda mengajukan masalah dengan informasi yang diberikan?
c. Mengapa anda memisalkan dengan permisalan tersebut?
d. Bagaimana anda menyelesaikan permasalahan tersebut?

\section{HASIL}

Berdasarkan penelitian yang dilakukan, didapatkan hasil bahwa kualitas pengajuan masalah matematika kedua subjek berada pada kategori 5 berdasarkan indikator Kriteria Kategori Kualitas Pengajuan Masalah Matematika Siswa. Hasil tersebut didasarkan pada hasil tes pengajuan masalah matematika pada materi SPLDV yang dikerjakan subjek dan hasil wawancara dengan subjek terkait proses pengajuan masalah yang telah dilakukan. Berikut langkah-langkah pengajuan masalah dan 
hasil yang diperoleh subjek diuraikan sebagai berikut;

\section{Subjek 1.}

Langkah pertama subyek 1 mengajukan masalah berdasarkan informasi yang disediakan, jenis pertanyaan yang telah disusun subyek merupakan jenis pertanyaan matematika.

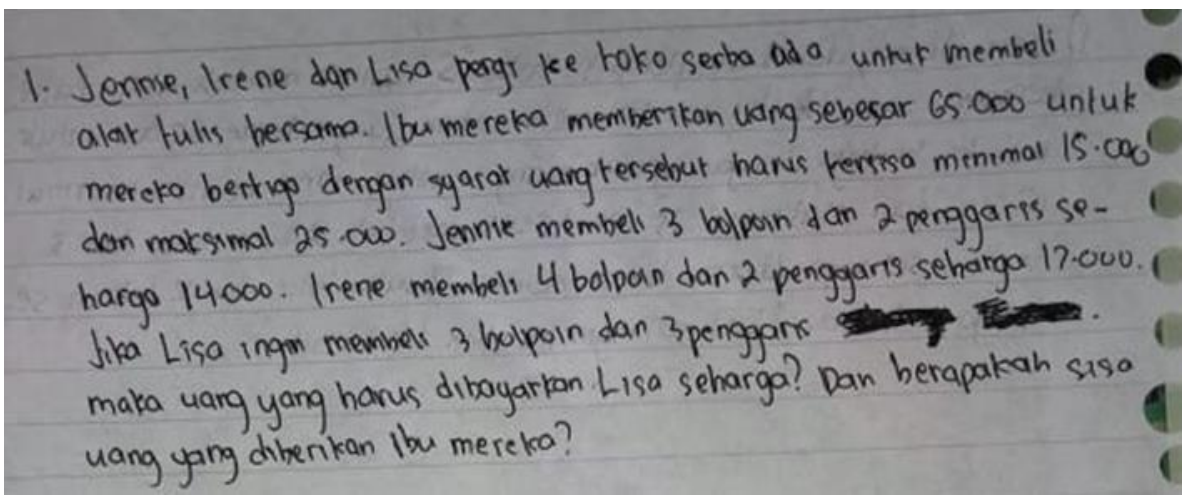

Gambar 1. Masalah yang diajukan subjek 1.

Langkah kedua yaitu berdasarkan pertanyaan matematika yg telah disusun oleh subyek, maka subyek mengandaikan atau membuat permisalan dari informasi baru di dalam masalah yang mereka buat.



Gambar 2. Permisalan yang digunakan subjek 1.

Langkah ketiga, subyek menggunakan metode eliminasi dan subtitusi untuk memecahkan permasalahannya dan menentukan hasil akhir dari masalah tersebut.

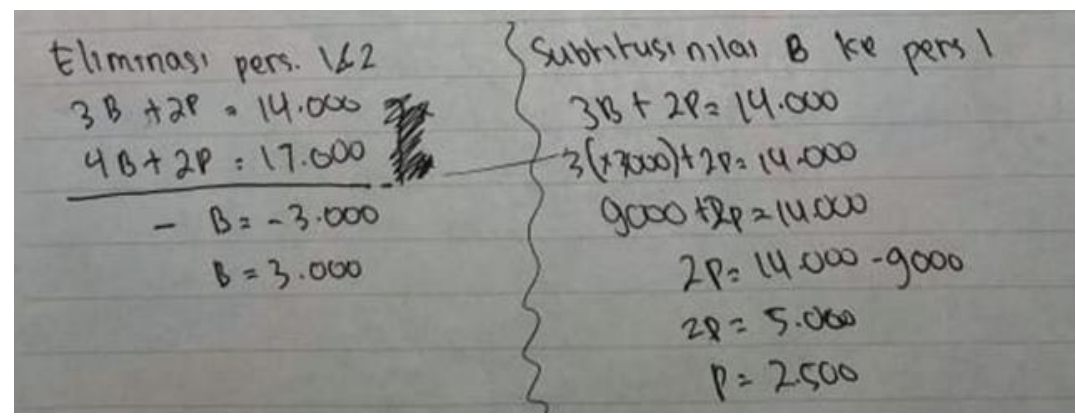

Gambar 3. Jawaban subjek 1 bagian 1. 


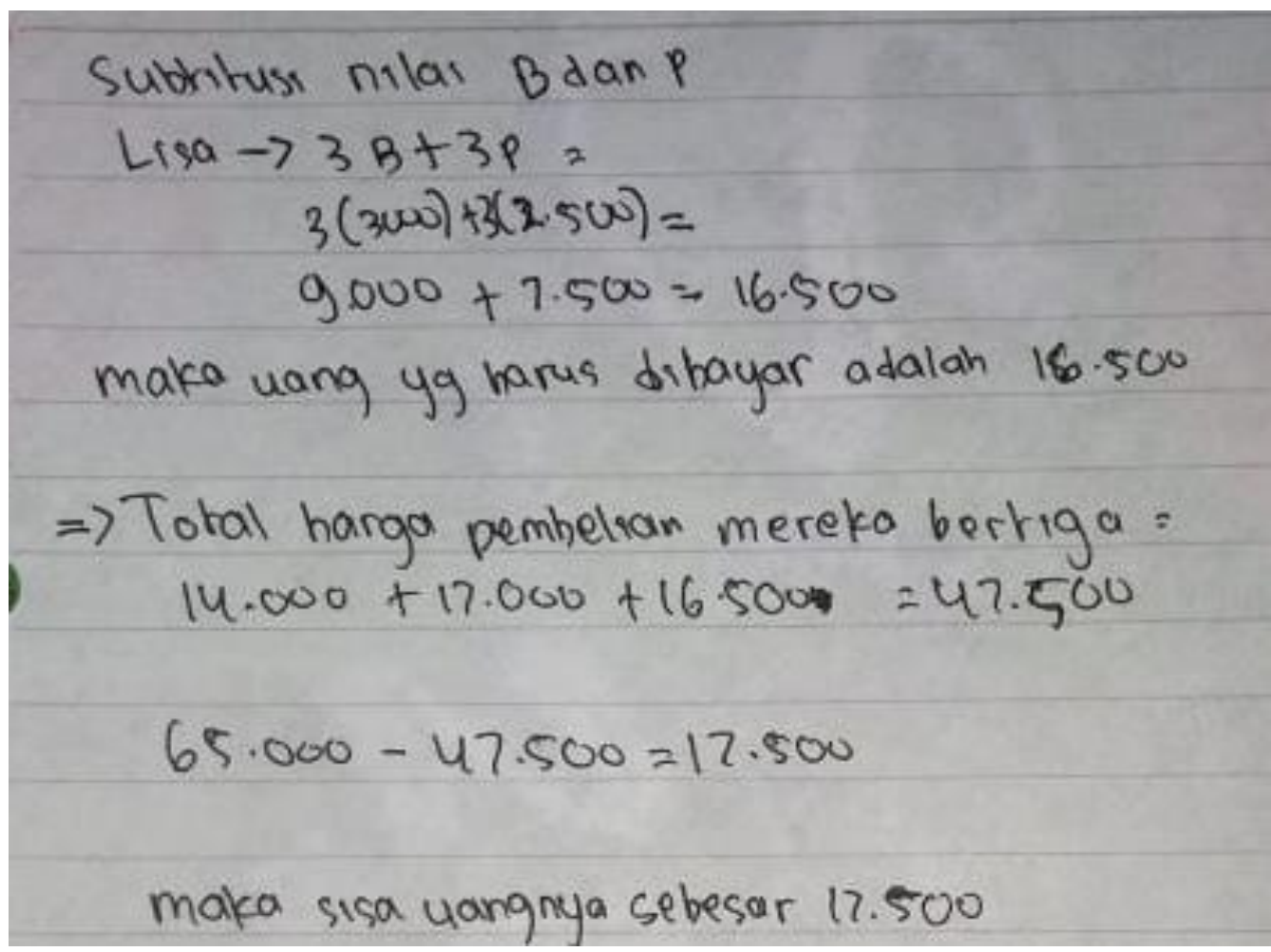

Gambar 3. Jawaban subjek 1 bagian 2.

Hasil wawancara Subjek 1 ;

Apa yang anda pahami dengan informasi yang diberikan?

Jawab : Diberikan uang sebesar 65.000 kepada 4 orang untuk membeli ATK dengan syarat uang itu harus tersisa minimal 15.000 dan maksimal 25.000

Bagaimana cara anda mengajukan masalah dengan informasi yang diberikan?

Jawab : Dari informasi tersebut saya memilih beberapa barang yang akan di beli dan menghitng semua total harga dari barang-barang yang di beli supaya tahu uang itu akan sisa berapa. Jika sisanya kurang dari batas minimal atau kelebihan dari batas maksimal yang di tentukan maka harus di ubah jumlah pembeliannya.

Mengapa anda memisalkan dengan permisalan tersebut?

Jawab : Karena barang yang saya pilih itu Bulpoint dan Penggaris maka saya misalkan B dan P .

Bagaimana anda menyelesaikan permasalahan tersebut?

Jawab : Saya menggunakan Metode Eliminasi,Subtitusi dan Gabungan untuk mencari nilai-nilai dari permisalan dan menyelesaikan permasalahannya.

\section{Subjek 2.}

Langkah pertama subyek 2 mengajukan masalah berdasarkan informasi yang disediakan, jenis pertanyaan yang telah disusun subyek merupakan jenis pertanyaan matematika. 


\section{Alisa, Maira, dan Frida sedang membeli peralatan rekolah} di Toko yang beroda dil. dekat rumah mereka: Mereka dibenkan uang oleh ayahnya rebesar Kp. 65.000 untuk membeli peralatan teriebut. Uang, teriebut harus tesisa minimal 15.000 dan maksimal 25.000. Alsa membeli 2 buku dan 1 bulpont seharga Rp. 12000 . Maira membeli 3 buku dan 2 bulpoint seharga $B p 19.500$. Frida Ingin membeli 1 buku dan 4 bulpant. Berapakah uang yang harus dibayarkan Frida? Dan berupakah sisa uang yang diberkan kepada Ayah inereka?

Gambar 4. Masalah yang diajukan subjek 2.

Langkah kedua yaitu berdasarkan pertanyaan matematika yg telah disusun oleh subyek, maka subyek mengandaikan atau membuat permisalan dari informasi baru di dalam masalah yang mereka buat.



Gambar 5. Permisalan yang digunakan subjek 2

Langkah ketiga, subyek menggunakan metode eliminasi dan subtitusi untuk memecahkan permasalahannya dan menentukan hasil akhir dari masalah tersebut. 


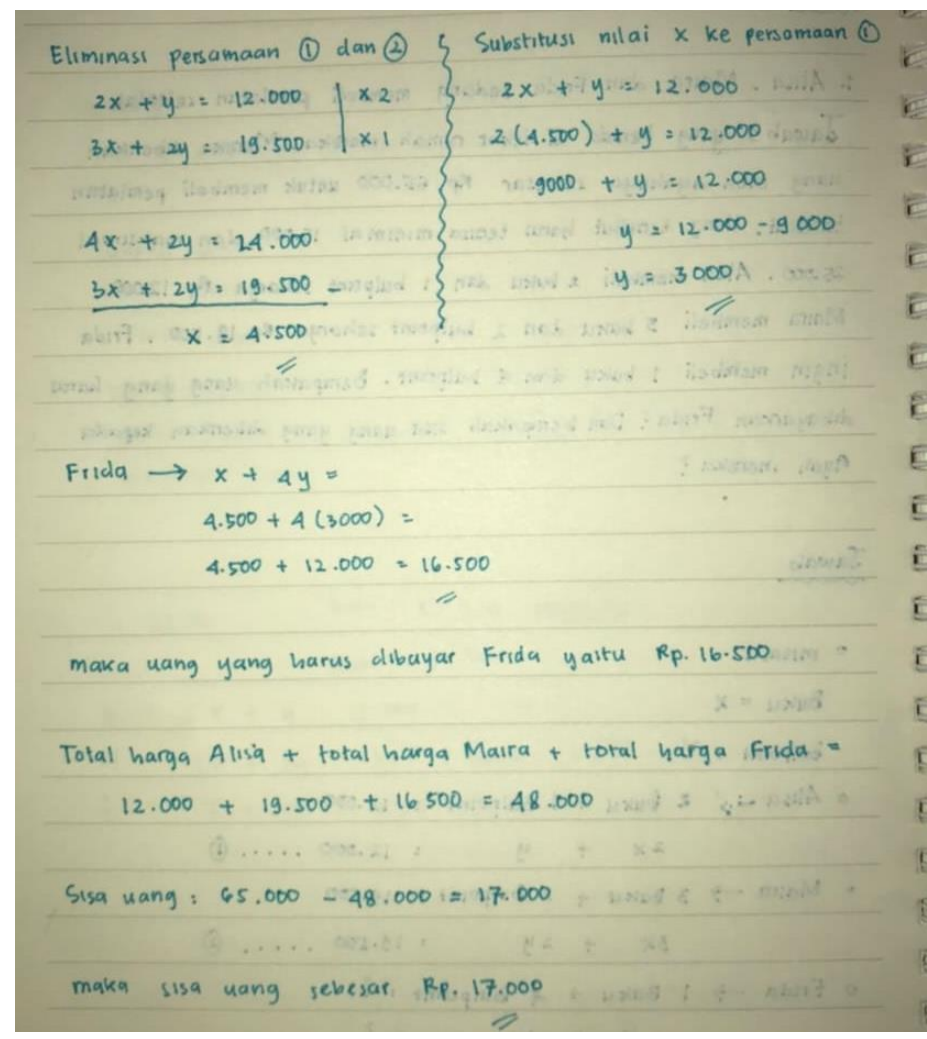

Gambar 6. Jawaban subjek 2.

Hasil wawancara Subjek 2 ;

Apa yang anda pahami dengan informasi yang diberikan?

Jawab : Seseorang memberikan uang sebesar 65.000 kepada 4 orang untuk membeli alat tulis sekolah tetapi uang itu harus tersisa minimal 15.000 dan maksimal 25.000 .

Bagaimana cara anda mengajukan masalah dengan informasi yang diberikan?

Jawab : Berdasarkan informasi yang diberikan, saya memilih 2 barang yang akan di beli kemudian mulai mencoba menentukan jumlahnya dan menghitung semua total harga dari barang-barang yang di beli untuk mengetahui sisa uangnya. Jika sisanya kurang dari batas minimal atau kelebihan dari batas maksimal yang di tentukan maka harus di ubah jumlah pembeliannya.

Mengapa anda memisalkan dengan permisalan tersebut?

Jawab : Karena biar mudah jadi saya misalkan dengan $\mathrm{x}$ dan $\mathrm{y}$.

Bagaimana anda menyelesaikan permasalahan tersebut?

Jawab : Menggunakan Metode Eliminasi, Subtitusi dan Gabungan untuk menyelesaikannya.

Setelah menganalisis hasil TPMM dan wawancara kedua subjek, maka kualitas pengajuan masalah kedua subjek termasuk kategori sangat tinggi, hasil ini di dukung oleh Teori Threshold dalam (Hayes, 1989) \& (Hidayat \& Anggareni, 2019) bahwa jika seseorang memiliki IQ diatas 120 
maka seseorang itu akan sangat sukses dalam kegiatan kreatif. Hasil jawaban subjek memenuhi kriteria sebagai berikut; Subyek mampu mengajukan masalah matematika sesuai dengan informasi yang diberikan, masing-masing masalah yang diajukan mengandung 5 hubungan semantik, kemudian dari segi sintaksis, masalah yang diajukan mengandung unsur pengandaian, kalimat yang disajikan dapat dipahami dengan baik dan terarah pada suatu masalah yang dapat diselesaikan lalu jika disajikan dalam bentuk diagram, dapat diinterpretasikan dengan baik dan cepat.

\section{KESIMPULAN}

Berdasarkan hasil penelitian dan pembahasan, dapat disimpulkan bahwa siswa dengan IQ superior memiliki kualitas pengajuan masalah matematika berkategori sangat tinggi. Subyek mampu memahami informasi yang diberikan peneliti, dan mampu mengajukan masalah matematika sesuai informasi yang disediakan. Subyek mampu membuat pertanyaan matematika yang dapat dikerjakan dan mengandung informasi baru.

\section{DAFTAR PUSTAKA}

Benedek, M., Jauk, E., Sommer, M., Arendasy, M., \& Neubauer, A. C. (2014). Intelligence, creativity, and cognitive control: The common and differential involvement of executive functions in intelligence and creativity. Intelligence, 46(1), 73-83. https://doi.org/10.1016/j.intell.2014.05.007

Depdiknas. (2007). Model-model Pembelajaran Matematika dan Ilmu Pengetahuan Alam. Jakarta: Depdiknas.

Evans, J. (1991). Creative Thinking in the Decision and Management Sciences. Cincinnati: SouthWestern Publishing Co.

Gomez, J. G. (2013). What we know about creativity. Journal of Advertising Research, 53(3), 238 239. https://doi.org/10.2501/JAR-53-3-238-239

Hayes, J. R. (1989). Cognitive Processes in Creativity. Handbook of Creativity, 18, 135-145. https://doi.org/10.1007/978-1-4757-5356-1_7

Hidayat, A. F., \& Anggareni, P. (2019). Proses Berpikir Kreatif Siswa dalam Pengajuan Masalah Matematika. Jurnal Ilmiah Dikdaya, 9(2), 209. https://doi.org/10.33087/dikdaya.v9i2.143

Panda, B. (2007). Advanced Educational Psychology. New Delhi: Discovery Publishing House.

Peraturan Menteri Pendidikan dan Kebudayaan Republik Indonesia No.58 Tahun 2014 tentang Kurikulum 2013 Sekolah Menengah Pertama/Madrasah Tsanawiyah, Menteri Pendidikan Nasional (2014). https://doi.org/10.1093/eurheartj/eht160

Mahmudi, A. (2011). Problem Posing untuk Menilai Hasil Belajar Matematika. Matematika Dan Pendidikan Karekter Dalam Pembelajaran.

Rahman, A. (2004). Dan Kategori Informasi.

Rahmawatin, A. (2013). Profil Kreativitas Siswa Smp Dalam Pengajuan Soal Matematika Ditinjau Dari Tingkat Iq. Gamatika, 3(2), 242452. 
Setyaningsih, T. D., Agoestanto, A., \& Kurniasih, A. W. (2014). Identifikasi Tahap Berpikir Kritis Siswa Menggunakan PBL dalam Tugas Pengajuan Masalah Matematika. Kreano: Jurnal Matematika Kreatif-Inovatif, 5(2), 180-187. https://doi.org/10.15294/kreano.v5i2.4544

Silver, E. A., \& Cai, J. (1996). An analysis of arithmetic problem posing by middle school students. Journal for Research in Mathematics Education, 27(5), 521-539. https://doi.org/10.2307/749846

Siswono, T. Y. E. (2004). Mendorong Berpikir Kreatif melalui Pengajuan Maslah (Problem Posing). Journal of Mathematics Education, 1(1), 23-27.

Siswono, T. Y. E. (2005). Upaya Meningkatkan Kemampuan Berpikir Kreatif Siswa Melalui Pengajuan Masalah. Pendidikan Matematika, 1, 1-15.

Siswono, T. Y. (2008). Model Pembelajaran Matematika Berbasis Pengajuan dan Pemecahan Masalah untuk Meningkatkan Kemampuan Berpikir Kreatif. Surabaya: Unesa University Press.

Suharnan. (2005). Psikologi Kognitif. Surabaya: Srikandi.

Suryabrata, S. (2006). Psikologi Pendidikan. Jakarta: PT. Raja Grafindo Persada.

Uno, H. (2005). Orientasi Baru dalam Psikologi Pembelajaran. Jakarta: Bumi Aksara.

Woolf, B., Aimeur, E., Nkambou, R., Lajoie, S., \& Eds. (2008). Intelligent Tutoring Systems. 9th International Conference, ITS. Montreal. 